POKROK $^{1}$

\title{
Theodor W. Adorno
}

Josefu Königovi

Pokud chceme skládat teoretické účty z kategorie pokroku, je třeba zaměřit se na ni z takové blízkosti, že ztratí zdání samožrejmosti jak ve svém pozitivním, tak negativním užití. Avšak taková blízkost zároveň znesnadňuje samo skládání účtů. Pojem pokroku se více než jiné pojmy rozchází se specifikací toho, co je jím vlastně míněno, tedy toho, co se vyvíjí (was fortschreite) ${ }^{2}$ a co nikoli. Kdo chce tento pojem precizně vypracovat, snadno zničí to, na co cílí. Subalterní obezřetnost, jež se zdráhá o pokroku hovořit, dokud nedokáže rozlišit pokrok v čem, čeho a ve vztahu k čemu, přesouvá jednotu momentů, jež se v pojmu vzájemně vypracovávají, v jejich prosté bytí vedle sebe. Svéhlavá teorie poznání, jež se domáhá exaktnosti tam, kde nemožnost jednoznačnosti patří $\mathrm{k}$ věci samé, se s věcí míjí, sabotuje vhled a slouží k uchování toho, co je špatné, snaživým zákazem uvažovat o tom, o čem by v době utopických i absolutně destruktivních možností chtělo vědomí těch, jež jsou do věci zapleteni, učinit zkušenost: zda existuje pokrok. Jako každý filosofický termín má i pokrok své ekvivokace; a tak jako v každém jiném pojmu ohlašují i zde něco společného. Co se dnes pokrokem myslí, víme vágně, avšak přesně: proto není možné tento pojem užívat dostatečně hrubě. Pedanterie v jeho užívání pouze klame ohledně toho, co on slibuje: odpověd’ na pochybnost a naději, že věci budou konečně lepší, že jednou budou lidé smět vydechnout. Již proto nelze přesně říci, co by si měli lidé pod pojmem pokroku představit, nebot' svízelností situace je, že kaž-

1 Přeloženo podle: T. W. Adorno, Fortschritt, in: týž, Gesammelte Schriften, X/2, vyd. R. Tiedemann, Frankfurt a. M. 1977, str. 617-638. Všechny poznámky v texu jsou poznámky překladatele. Text je redakčně krácen (výpustku vyznačujeme třemi tečkami).

2 Německé sloveso „fortschreiten“, jež má stejný kořen jako substantivum ,pokrok“ - „Fortschritt“ -, nemá český slovesný ekvivalent. V tomto článku je důsledně překládáno jako „vyvíjet se“. Pro ostatní termíny znamenající rovněž „,vyvíjet se“ např. ,,entfalten“ či ,entwickeln“ - jsou vždy užity jiné tvary, nejčastěji „,rozvíjet se“. 
dý tuto svízelnost cítí, avšak chybí slovo, jež by přineslo řešení. Pravdu mají jen takové reflexe o pokroku, jež se do něj hluboce noří, a přesto si udržují distanc, ustupují od ochromujících fakt a speciálních významů. Dnes se takovéto reflexe zaostřují v úvaze, zda je lidstvo schopné odvrátit katastrofu. Život lidstva ohrožují formy jeho vlastního celkového společenského zřízení potud, pokud se nevytvoří celkový subjekt, jenž si je vědom sebe samého, a ten nezakročí. Pouze na něj přešla možnost pokroku, možnost odvrácení krajního, totálního neštěstí. Vše ostatní, co se týká pokroku, by muselo vykrystalizovat na něm. Materiální nedostatek, jenž, jak se zdálo, se dlouho pokroku vysmíval, je potenciálně odstraněn: vzhledem ke stavu technických výrobních sil by již nikdo na Zemi nemusel strádat. Zda bude nedostatek a utlačování pokračovat - oboje je jedním -, o tom rozhoduje jedině zamezení katastrofě skrze rozumné zřízení celé společnosti jakožto lidstva. Kantův návrh nauky o pokroku byl také vázán na ,ideu člověka“: ${ }^{3}$ „Protože jen ve společnosti, a to té, která má největší svobodu, tudíž všeprostupující antagonismus svých členů, a přitom nejpřesnější vymezení a zajištění hranic této svobody, aby mohla existovat se svobodou každého druhého - poněvadž jen v ní může být dosažen nejvyšší záměr přírody v lidstvu, totiž rozvinutí všech jeho vloh -, prríroda také chce, aby si lidstvo tento antagonismus, stejně jako všechny účely svého určení, zjednalo samo -, tak musí být společnost, v níž se nachází svoboda pod vnějšími zákony v nejvyšší možné míře spojena s nepopiratelnou mocí, tj. dokonale spravedlivé občanské zrrízení musí být nejvyšším úkolem př́rody pro lidský druh; nebot' může jen prostřednictvím rozvratu a jeho uskutečnění dosáhnout svých ostatních záměrů s naším rodem. “4 Pojem dějin, v němž by měl své místo pokrok, je emfatický, je pojmem kantovského všeobecna či světoobčanství, nikoli pojmem partikulární sféry života. Avšak odkázanost pokroku k totalitě se jako osten obrací proti němu. Vědomí tohoto faktu oživuje Benjaminovu polemiku proti spojování pokroku a lidstva, již předkládá v tezích $O$ pojmи dějin a jež je patrně tím nejzávažnějším, co bylo myšleno ke kritice ideje pokroku, jak ji zastávali ti, jež lze hrubě politicky nazvat jako progresivisty: „Pokrok, jak si jej malovali sociální demokraté, byl za prvé pokrokem samotného lidstva (nejenom jeho dovedností a znalostí). " $\mathrm{Jak}$

3 I. Kant, Idea všeobecných dějin ve světoobčanském smyslu, in: týž, Studie $k$ dějinám a politice, přel. J. Loužil - P. Stehlíková - K. Novotný, Praha 2016, str. 11.

4 Tamt., str. 14.

5 W. Benjamin, O pojmu dějin, in: týž, Teoretické pasáže, přel. M. Ritter, Praha 2011, str. 313. 
málo se však lidstvo tel quel vyvíjí podle reklamního receptu „stále lepší a lepší“, právě tak málo je možná idea pokroku bez ideje lidstva; smyslem Benjaminovy pasáže by tedy mohla být spíše výčitka, že sociální demokraté zaměňovali pokrok $\mathrm{v}$ dovednostech a znalostech s pokrokem lidstva, ne že by chtěl autor odstranit pokrok z filosofické reflexe. Pokrok získává u Benjamina své oprávnění v nauce, že představa štěstí dosud nenarozených generací - bez níž není možné mluvit o pokroku - s sebou nezcizitelně přináší představu vykoupení. ${ }^{6}$ Tím je potvrzena zaměřenost pokroku na přežití rodu: nelze tak předpokládat žádný pokrok, jako kdyby již existovalo lidstvo vůbec, a mohlo se tedy vyvíjet. Pokrok by spíše byl nejprve vytvořením lidstva, jehož perspektiva se otevírá vzhledem k vyhlazení. Z toho vyplývá skutečnost, že - jak učí Benjamin - pojem universálních dějin nemá být zachráněn; tento pojem je pochopitelný jen tak dlouho, dokud umožňuje věrit v iluzi lidstva, které již existuje a které je již v sobě samém sladěné a jednotně se pohybuje vzhůru. Zůstává-li lidstvo zajato totalitou, kterou samo buduje, pak ještě - dle Kafkových slov - k žádnému pokroku vůbec nedošlo, zatímco však pouze totalita ho umožňuje myslet. Nejsnáze to lze objasnit pomocí určení lidstva jako něčeho, co vůbec nic nevylučuje. Pokud by bylo totalitou, která již v sobě neobsahuje žádný ohraničující princip, bylo by také zbaveno nutnosti, jež všechny členy takovému principu podřizuje, a tedy by již déle nebylo totalitou: žádnou vynucenou jednotou. Pasáž Schillerovy Ódy na radost: „V díle tom kdo nezdar tuší, od nás ber se s pláčem dál!“‘, 7 jež ve jménu všeobjímající lásky vyhošt'uje toho, komu láska nebyla přiřčena, přiznává nechtěně pravdu o buržoazním, zároveň totálním i partikulárním pojmu lidstva. To, co ve verši jménem této ideje postihuje nemilovaného či lásky neschopného, odhaluje tuto ideu nejinak než afirmativní násilí, s nímž ji vytlouká Beethovenova hudba; je stěží náhodou, že báseň slovem „krást“8 $v$ části o pokoření nešt’astného, jemuž tak bude znovu odepřena radost, vyvolává asociace ze sféry vlastnictví a kriminologie. K pojmu totality náleží, tak jako v politicky totalitárních systémech, ustavičný antagonismus; tak jsou zlé mytické slavnosti z pohádek definovány těmi, kdo nebyli pozváni. Pouze tam, kde by zanikl ohraničující

\footnotetext{
6 Tamt., str. 307.

7 Český překlad Pavla Eisnera (P. Eisner, Lessing, Goethe und Schiller in tschechischen Übersetzungen, Prag 1918).

8 Adorno využívá dvojznačnosti německého slovesa „stehlen“, jež stojí v originále na místě českého „brát se dál““. „Stehlen“ primárně znamená „krást“, avšak také „vykrást se“ (odněkud).
} 
princip totality, i kdyby to byl pouze př́kaz být jí rovný, existovalo by lidstvo, a ne jeho přelud.

Historicky byla koncepce lidstva implikována již v teorému o universálním státě, jak jej koncipovala střední stoa a který objektivně přinejmenším směřoval $\mathrm{k}$ pokroku, jakkoliv mohla být idea pokroku předkřest'anské antice cizí. Skutečnost, že se onen stoický teorém rovněž hodil k odůvodnění imperiálních nároků Říma, vypovídá cosi o tom, co postihlo pojem pokroku jeho identifikací s rostoucími „,dovednostmi a znalostmi“. Existující lidstvo je podstrčeno namísto toho dosud nenarozeného a dějiny se bezprostředně stávají dějinami spásy. To byl prototyp představy pokroku až k Hegelovi a Marxovi. V Augustinově civitas dei je tato představa vázána na vykoupení skrze Krista jakožto na historicky zdařené; pouze již vykoupené lidstvo může být sledováno $\mathrm{v}$ tom, jak se pohybuje - poté, co padlo rozhodnutí díky milosti, jež byla lidstvu dána - skrze kontinuum času až k nebeské říši. Snad bylo nešt'astným osudem pozdějšího myšlení pokroku, že od Augustina převzalo imanentní teleologii a koncepci lidstva jako subjektu veškerého pokroku, zatímco křest'anská soteriologie vybledla v dějinně-filosofických spekulacích. Tím se idea pokroku přesunula do civitas terrena, jejího augustinovského protějšku. Také u dualistického Kanta se má vyvíjet podle svého vlastního principu, podle své „přirozenosti“. Avšak v takovémto osvícenství, jež klade pokrok k lidstvu do rukou lidstva samého, a tím konkretizuje jeho ideu jako to, co má být uskutečněno, číhá konformistické potvrzení toho, co pouze je. Auru vykoupení získává poté, co vykoupení nenastalo a zlo trvalo v nezmenšené podobě. Této nedohledně dalekosáhlé modifikaci pojmu pokroku se nedalo vyhnout. Jako se emfatický nárok zdařilého vykoupení stal protestem vůči pokřest’anským dějinám, tak i v augustinovském theologumenon imanentního pohybu rodu vstříc blaženému stavu již spočíval motiv neodvratitelné sekularizace. Časovost samotného pokroku - jeho jednoduchý pojem - ho již sepnula s empirickým světem; ovšem bez takovéto časovosti by to, co je ohavné na běhu světa, bylo zprvu skutečně v myšlence zvěčněno, samo stvoření by se stalo dílem gnostického démona. U Augustina lze vypozorovat nerozlučnou konstelaci idejí pokroku, vykoupení a imanentního chodu dějin, jež nesmějí přejít jedna v druhou, jestliže se nemají vzájemně zrušit. Bude-li pokrok kladen na roveň vykoupení jakožto transcendentní intervenci vůbec, pak spolu se svou časovou dimenzí ztratí i veškerý srozumitelný význam a vyprchá do bezdějinné theologie. Bude-li však zprostředkován v dějinách, pak hrozí jejich zbožštění a - v reflexi pojmu stejně jako v realitě - protismysl, že pokrokem bude již to, co pokrok 
inhibuje. Pomocné konstrukce imanentně-transcendentního pojmu pokroku odsuzují samy sebe již svou nomenklaturou.

Velikost augustinovské nauky byla velikostí toho, co je poprvé. Měla v sobě všechny propasti ideje pokroku a snažila se je teoreticky překonat. Struktura její doktríny přivádí antinomický charakter pokroku k jeho nezmírněnému výrazu. U Augustina je již, stejně jako poté znovu od Kanta dál na úrovni sekulární filosofie dějin, antagonismus v centru onoho dějinného pohybu, jenž by byl, jakožto namîrený k nebeské řîši, pokrokem; tento pohyb je pro Augustina bojem mezi pozemským a nebeským. Všechno pozdější myšlení pokroku obdrželo svou ponornou hloubku od tíhy dějinně vzrůstajícího neštěstí. I když u Augustina představuje vykoupení telos dějin, dějiny do něj bezprostředně neústí a ani vykoupení k nim nepřichází zcela nezprostředkovaně. Vykoupení je do dějin zapuštěno skrze božský světový plán, ovšem po pádu do hříchu je vůči nim protichůdné. Augustin poznal, že vykoupení a dějiny nejsou jedno bez druhého ani jedno v druhém, nýbrž že se nacházejí v napětí, jehož nahromaděná energie nechce vposled nic menšího než zrušení a překonání dějinného světa samého. Jestliže lze v době katastrofy ještě vůbec myslet myšlenku pokroku, pak kvůli ničemu menšímu. Pokrok lze právě tak málo ontologizovat a nereflektovaně připisovat bytí jako - což ovšem vyhovuje lépe novějším filosofům - úpadek. Aby se dal v predikativním soudu vypovědět o světě pokrok, na to má príliš málo dobrého ve světě moc, avšak žádné dobro, ani jeho stopa, neexistuje bez pokroku. Pokud - podle určité mystické nauky - mají mít nitrosvětské události, až k těm zcela nejnepatrnějším, značné konsekvence pro život absolutna samého, pak je cosi podobného jistě pravdivé o pokroku. Každý jednotlivý rys v souvislosti zaslepení je však relevantní vzhledem k jejímu možnému konci. Dobro je to, co se vyprošt’uje, co nachází řeč a otevírá oči. Jakožto vyprošt'ující se je zapleteno v dějinách, jež bez toho, že by se jednoznačně nasměrovaly ke smíření, nechávají v postupu svého pohybu zablesknout jeho možnost.

Momenty, v nichž má pojem pokroku svůj život, jsou podle tradiční zvyklosti zčásti filosofické, zčásti společenské. Bez společnosti by jeho představa byla zcela prázdná; všechny jeho elementy jsou odečteny z ní. Pokud by společnost nepřešla od sbírající a lovící hordy k zemědělství, od otroctví k formální svobodě subjektů, od strachu z démonů $\mathrm{k}$ rozumu, od nedostatku k ochraně před morem a hladomorem a ke zlepšení životních podmínek vůbec; pokud by se člověk snažil získat ideu pokroku čistě more philosophico, tedy utkat ji z bytnosti času, pak by neměla vůbec žádný obsah. Jakmile však smysl určitého pojmu nutí 
k přechodu do fakticity, nelze tento přechod svévolně zastavit. Samu ideu smíření - transcendentní telos všeho pokroku, podle měřítek konečného - nelze vylomit z imanentního procesu osvícenství, jež odstraňuje úzkost a - nakolik staví lidské bytosti jako odpověd’ na otázky lidských bytostí - získává pojem lidství, jenž samotný se pozvedá nad imanenci světa. Nicméně pokrok nesplývá se společností, není s ní identický; tak, jak existuje, je někdy společnost jeho protikladem. Dokud filosofie $\mathrm{k}$ něčemu byla, byla rovněž naukou o společnosti; jenže od té doby, co se bez námitek vzdala své moci, musí se filosofie od společnosti přiznaně odlišit; čistota, do níž nazpět upadla, je špatným svědomím její nečistoty, komplicity se světem. Pojem pokroku je filosofický v tom, že zatímco artikuluje pohyb společnosti, zároveň mu protiřečí. Jakožto společensky vzniklý vyžaduje kritickou konfrontaci s reálnou společností. Moment vykoupení, at' už jakkoliv sekularizovaný, je v něm nesmazatelně př́ítomný. Skutečnost, že se pokrok nenechá redukovat ani na fakticitu, ani na ideu, ukazuje na jeho vlastní rozpor. Nebot' v něm obsažený osvícenský moment, jenž končí ve smírrení s přírodou tím, že konejší její děsy, je příbuzný momentu ovládání přírody. Model pokroku, byt' by byl přesunut na božstvo, je kontrolou přírody vně i uvnitř člověka. Utlačování, jež bude skrze takovouto kontrolu praktikováno a které má svou nejvyšší duchovně-reflexivní formu v principu identity rozumu, reprodukuje tento antagonismus. Čím více bude vládnoucím rozumem ustavována identita, tím více bezpráví postihne to, co je neidentické. Bezpráví se dědí skrze resistenci neidentického. Resistence dále posiluje utlačující princip, zatímco ono utlačované se otráveno vleče dále. Všechno v celku se vyvíjí, pouze celek dodnes nikoli. Goethovské „A všechno naléhání, všechno zápasení / Je věčným klidem v Pánu Bohu“9 kodifikuje zkušenost právě této skutečnosti a hegelovská doktrína procesu světového ducha, absolutní dynamiky jakožto obracející se zpět k sobě samé, či dokonce jeho hry se sebou samým, je goethovské sentenci nesmírně blízko. K jejímu názoru lze doplnit pouze jednu nota bene: že onen celek ve svém pohybu zůstává v klidu, nebot' nezná nic mimo sebe, a tedy není božským absolutnem, nýbrž jeho protikladem, jejž nevědomě vytvořilo myšlení. Kant se ani neohnul před tímto klamem, ani neabsolutizoval zlom. Učil-li na nejvznešenějším místě své filosofie dějin, že antagonismus, zapletenost pokroku v mýtu, v uzavření přírody $\mathrm{z}$ ovládání přírody, krátce $\mathrm{v}$ říši nesvobody, směřuje pomocí vlastního zákona $\mathrm{k}$ říši svobody - později se z toho stala Hegelova lest rozumu -,

9 Pasáž pochází z cyklu básní Krotké Xenie, překlad je náš vlastní. 
neříká se zde nic menšího, než že podmínkami možnosti smîrení je jeho opak, podmínkami možnosti svobody je nesvoboda. Kantova nauka se nachází v zlomovém bodě. Koncipuje ideu onoho smírení jakožto imanentního antagonistickému „rozvoji“ tím, že je vyvozuje ze záměru, jejž příroda skýtá pro člověka. Na druhou stranu je dogmaticko-racionální strnulost, s níž je takovýto záměr prrírodě připisován, jako by sama nebyla součástí vývoje a jako by se tím tedy neměnil sám její pojem, výrazem onoho násilí, jež na přírodě páchá identitu kladoucí duch. Statika pojmu přírody je funkcí dynamického pojmu rozumu; čím více se rozum odtrhává od neidentického, tím více se příroda stává residuálním caput mortuum, což ulehčuje vybavit ji kvalitami věčnosti, jež posvěcují její cíle. „Záměr“ nelze vůbec myslet, pokud přírodě nebude připsán rozum. Ještě $\mathrm{v}$ metafyzickém užití pojmu př́rody, $\mathrm{k}$ němuž přistupuje na onom místě Kant a které ho přibližuje transcendentní věci o sobě, zůstává příroda právě tak produktem ducha jako v Kritice čistého rozu$m u$.Zkrotil-li duch přírodu tím, že se dle Baconova programu přírodě na všech svých úrovních vyrovnal a připodobnil, pak na kantovské úrovni projikoval sebe sama zpět na přírodu - nakolik má příroda být absolutní, a ne jen konstituovanou - kvůli možnosti smîrení, v němž ovšem primát subjektu není nijak umenšen. Na místě, kde se Kant nejvíce přibližuje k pojmu smíření, tedy v myšlence, že antagonismus končí svým zrušením, zaznívá heslo o společnosti, v níž je svoboda „spojena s nepopiratelnou mocí“. Ale dokonce i řeč o moci připomíná dialektiku pokroku samého. Jestliže ustavičné utlačování, jež zplodilo pokrok, také vždy rovněž pokrok zastavovalo, dovolilo především - jakožto emancipace vědomí - teprve poznat antagonismus a celek zaslepení, čili předpoklad pro urovnání tohoto antagonismu. Pokrok, jejž vytvořilo ono vždy stejné, spočívá v tom, že konečně nějaký pokrok může začít, a to v každém okamžiku. Připomíná-li obraz vyvíjejícího se lidstva obra, jenž se po odvěkém spánku dává pomalu do pohybu, a poté zuří a zadupává vše, co mu přijde do cesty, pak je jeho neohrabané probuzení jediným potenciálem $\mathrm{k}$ dospělosti, $\mathrm{k}$ tomu, že uzavřenost přírody, do níž pokrok sám sebe zařazuje, nebude mít poslední slovo. Po eony neměla otázka po pokroku žádný smysl. Klade se poprvé poté, co byla osvobozena dynamika, z níž mohla být extrapolována idea svobody. Je-li pokrok - od Augustina znamenající přenesení přírodního životního běhu jednotlivce, rozepjatého mezi zrozením a smrtí, na rod - tak mytický jako představa cesty, na níž je př́kaz osudu značen hvězdami, pak je jeho idea právě tak zcela antimytologická a rozráží cyklický pohyb, k němuž náleží. Pokrok znamená: vystoupit z kletby, tedy i z kletby pokroku, jenž je sám př́rodou, 
tím, že si lidstvo uvědomí svou vlastní přírodní tendenci k růstu a zastaví panství, jež vykonává nad přírodou a skrze něž pokračuje panství př́írody. Natolik se dá říci, že pokrok se děje tam, kde končí.

Nikde jinde zřejmě není onen paradox, že pokrok existuje, a přesto neexistuje, tak drastický jako ve filosofii, kde je doma sama idea pokroku. Jakkoli přesvědčivé mohou být ony kritikou zprostředkované přechody od jedné autentické filosofie k druhé, tvrzení, že by mezi nimi, mezi Platónem a Aristotelem, Kantem a Hegelem, či dokonce v universálních dějinách filosofie vůbec, existoval pokrok, zůstává pochybným. To však nezavinila ani invariantnost domnělého filosofického předmětu, pravdivého bytí, jehož pojem v dějinách filosofie neodvolatelně zanikl, ani nebylo možné obhajovat pouze estetický pohled na filosofii, jenž by imponující myšlenkovou architekturu, či dokonce ominózní velké myslitele stavěl výše než pravdu, jež v žádném případě není totožná s imanentní uzavřeností a přísností filosofií. Zcela farizejský a klamný by byl verdikt, že pokroky ve filosofii ji odváděly pryč od toho, co žargon špatných filosofií pokřtil jako její naléhavost: tím by se potřeba stala garantem pravdivostního obsahu. Spíše jsou ony nevyhnutelné a pochybné pokroky toho, co má své hranice ve svém tématu, tématu hranic, kladeny principem rozumu, bez nějž nemůže být filosofie myšlena, nebot' bez něj nemůže být myšleno vůbec nic. Jeden pojem za druhým padá do orku mytična. Filosofie žije v symbióze s vědou; nemůže se od ní oprostit bez dogmatismu, vposled bez upadnutí do mytologie. Její obsah by však spočíval ve vyjádření toho, co bylo opomenuto či odstřiženo vědou, dělbou práce a reflexivními formami provozu sebezáchovy. Tím se zároveň její pokrok vzdaluje od toho, k čemu by se měla vyvíjet; síla zkušeností, jež filosofie registruje, je oslabována tím víc, čím více ji cepuje scientifistická výbava. Pohyb, jejž filosofie jako celek vykonává, je čistou sobě-rovností jejího principu. Filosofie se děje vždy rovněž ke škodě toho, co by měla pochopit a co může pochopit pouze díky sebereflexi, skrze niž opouští pozici tvrdošíjné bezprostřednosti - hegelovsky: filosofie reflexe. Filosofický pokrok si z nás dělá blázny, nebot' čím těsněji spojuje souvislosti zdůvodnění, čím odolnější se jeho výpovědi stávají vưči ranám a bodnutím, tím více se vždy stává myšlením identity. Oplétá své předměty sítí, která se tím, že zacpává díry toho, čím sama není, troufale tlačí na místo věci samé. Nakonec se ovšem zdá, v souladu s reálnými involučními tendencemi společnosti, že se na pokroku filosofie mstí skutečnost, jak málo pokroku bylo ve filosofii dosaženo. Tvrdit, že došlo k pokroku od Hegela k logickým pozitivistům, jež jej odbývají 
jako nejasného či bezesmyslného, není než komické. Ani filosofie není chráněna, at' už v omezeném zvědečtění, či v odložení rozumu, před upadnutím do onoho regresu, který jistě není lepší než ona škodolibě posmívaná víra v pokrok.

Konvergence totálního pokroku s negací pokroku má svůj původ v principu buržoazní společnosti, jež pojem pokroku stvořila, tedy ve směně. Ta je racionální podobou mytické věčné stejnosti. V každém jednotlivém aktu směny odvolává jeden akt druhý na základě principu „stejné za stejné“; saldo vychází. Byla-li směna správná, nic by se nemělo stát, vše zůstává při starém. Zároveň je ale tvrzení pokroku, jež protiřečí tomuto principu, natolik pravdivé, nakolik je doktrína stejného za stejné lživá. Odjakživa, nikoli teprve od kapitalistického přivlastnění nadhodnoty při směně zboží - pracovní síly za náklady na její reprodukci, dostává společensky mocnější kontrahent více než jeho protějšek. Skrze toto bezpráví nastává ve směně cosi nového. Proces, jenž proklamuje svou vlastní statiku, je dynamizován. Pravda expanze se živí lží stejnosti. Společenské akty se v celkovém systému musí vzájemně rušit, a přece nerušit. Kde buržoazní společnost dostačuje pojmu, jejž chová sama o sobě, tam nezná žádný pokrok; kde ho zná, dopouští se zločinu na vlastním zákonu, v němž již tento přečin spočívá, a spolu s nerovností zvěčňuje bezpráví, nad nějž by se měl pokrok povznést. Bezpráví je ale zároveň podmínkou možné spravedlnosti. Naplnění vždy znovu porušované směnné smlouvy by konvergovalo s jejím zrušením; směna by zmizela, kdyby bylo směněno opravdu stejné za stejné; opravdovým pokrokem by nebylo pouze to, co je jiné vůči směně, nýbrž spíše směna přivedená $\mathrm{k}$ sobě samé. Tak přemýšleli antipodi Marx a Nietzsche; Zarathustra postuluje, že člověk bude vykoupen od odplaty. Nebot' odplata je mytickým pravzorem směny; jak dlouho bude panováno skrze směnu, tak dlouho bude panovat mýtus. - Zkř́ižení stále stejného a nového ve směnném vztahu se manifestuje v imagines pokroku za buržoazního industrialismu. Na těchto imagines proto působí paradoxně, že se vůbec ještě stává něco jiného, že stárnou, nebot' prostřednictvím techniky se věčná stejnost principu směny stupňuje ve vládu opakování v oblasti produkce. Sám životní proces tuhne ve výraz stále stejného; odtud onen šok, jejž způsobují fotografie z devatenáctého a nyní již i z raného dvacátého století. Nesmysl exploduje: něco se děje tam, kde fenomén říká, že nic víc by se dít nemělo; jeho habitus se stává děsivým. V děsu se děs systému stahuje do jevu; čím více systém expanduje, tím více tvrdne v to, čím odjakživa byl. Co Benjamin nazýval dialektikou v klidu, není ani tolik jistou platonizující sedlinou jako spíše pokusem učinit tento pa- 
radox filosoficky vědomým. Dialektické obrazy: to jsou dějinně-objektivní archetypy oné antagonistické jednoty klidu a pohybu, jež definuje onen nejobecnější buržoazní pojem pokroku.

Svědky skutečnosti, že dialektický pohled na pokrok potřeboval korekturu, byli Hegel i Marx. Dynamika, již učili, není myšlena tak docela jako dynamika, nýbrž v jednotě se svým protikladem, s tím, co je pevné a neústupné a z čeho jediného lze vůbec dynamiku odečíst. Marx, jenž kritizoval všechny představy přirozeného růstu společnosti jako fetišistické, odmítl rovněž, proti lassallovskému Gothajskému programu, absolutizaci dynamiky v nauce o práci jako jediném prameni společenského bohatství; a uznal možnost recidivy do barbarství. Více než pouhou náhodou může být skutečnost, že Hegel navzdory své slavné definici dějin nemá žádnou vypracovanou teorii pokroku a že se Marx sám podle všeho snažil vyvarovat tohoto slova, a to i na onom stále znovu citovaném programatickém místě předmluvy Ke kritice politické ekonomie. Dialektické tabu nad pojmovými fetiši, dědictví starého antimytologického osvícenství ve fázi jeho sebereflexe, se prodlužuje také na kategorii, jež kdysi změkčovala zvěcnění, na kategorii pokroku, jenž klame, jakmile si jakožto jednotlivý moment usurpuje celek. Fetišizace pokroku posiluje jeho partikularitu, jeho omezení na techniky. Pokud by pokrok opravdu ovládal onen celek, jehož pojem v sobě nese znamení jeho násilnosti, pak by pokrok již nebyl totalitárním. Pokrok není žádnou uzavírající kategorií. Chce překazit triumf radikálního zla, nikoli triumfovat sám. Jsou myslitelné poměry, v nichž kategorie pokroku ztratí svůj smysl, a které přesto nejsou poměry universální regrese, jež se dnes s pokrokem spolčuje. Pak by se pokrok přeměnil v resistenci vůči ustavičnému nebezpečí recidivy. Pokrok je touto resistencí na všech stupních, nikoli odevzdáním se postupu skrze ně. 